TITLE:

\title{
Versal deformation of reflexive modules over rational double points(Abstract_要旨)
}

AUTHOR(S):

Ishii, Akira

CITATION:

Ishii, Akira. Versal deformation of reflexive modules over rational double points. 京都大学, 2000, 博士(理学)

ISSUE DATE:

2000-01-24

URL:

http://hdl.handle.net/2433/181457

RIGHT: 


\begin{tabular}{|c|c|}
\hline 氏 & 紧＼cjkstart并 \\
\hline 学位(専攻分野) & 博 士 \\
\hline 学位記 番号 & 論 理 博 第 1368 号 \\
\hline 学位授与の日付 & 平成 12 年 1 月 24 日 \\
\hline 学位授与の要件 & 学位規則第 4 条第 2 項該当 \\
\hline 学位論文題目 & $\begin{array}{l}\text { Versal deformation of reflexive modules over rational double points } \\
\text { 有理二重点上の反射的加群の半普遍変形 }\end{array}$ \\
\hline
\end{tabular}

論文調查委員 教 授) 丸山正樹教 授上野健爾 助教授 森脇 淳

\section{論 文内容 の 要 旨}

申請者は主論文において, 二次元有理特異点上の反射的加群の versal deformation について考察している。特に, 有理二 重点の場合に, 反射的加群の mini-versal deformation space の同型類による stratification について, strata の closure relation 及び minimal strata の特異点の様子を決定している。これはルート系の言葉を用いて簡明に記述される美しい結 果である。以下に主論文の概要を示す。

まずこのような問題を考察するにあたって, 局所環上の加群の変形に関する一般論を必要とする。すなわち, 代数的閉体 $k$ 上の（適当な有限性を持つ）局所環上の有限生成加群 $E$ で, 閉点以外では局所自由なあのの变形理論が必要である。申請 者は, 二つの变形函手 $D e f_{E}$ と $D e f_{E}^{\prime}$ について考察している。Def $f_{E}$ は通常の $E$ の変形に対応するすのであり, Def $f_{E}^{\prime}$ は, 孤立特 異点上の場合にのみ定義されるが, determinant の変形が自明であるような変形に対応するあのである。主論文の第 2 節に おいては, Schlessinger, Artin, Elkik の手法に従い，これらの変形函手が pro-representable であり，かつ代数化可能であ

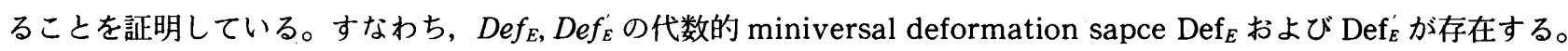

次に主論文の第三節において, 二次元正規特異点の場合に, 反射的加群 $E$ の変形と, あるねじれなし加群 $I$ の变形との関 係を考察している。特に, 二次元 Gorenstein 正規特異点（非特異な場合は除く）上で, 極大イデアルの自明加群による非自 明な拡大として得られる反射的加群 $E$ について，Def ${ }_{E}^{\prime}$ はその特異点自身に同型であることを示している。

第四節からは, 二次元有理特異点上の反射的加群の場合に限り, $\operatorname{Def}_{E}^{\prime}$ やその部分多様体の特異点解消になるあのを構成し ている。 $X=\operatorname{Spec} \mathcal{O}$ を次元有理特異点 $\pi: \tilde{X} \rightarrow X$ をその極小特異点解消とする。 $R$ をネーター的 $k$-代数とし， $E_{R}$ を $D e f^{\prime}$ $(R)$ の元の定める反射的 $\mathcal{O}$-加群の平坦族とする。 $d \in \mathrm{Pic} \tilde{X}$ と $R$ 上のスキーム $S$ に対し $\mathscr{F}_{E_{R}}^{d}(S)$ で次のような組 $\left(\mathscr{E}_{S}, \varphi\right)$ の 同型類の集合を表す： $\mathscr{E}_{S}$ は $S$ のパラメトライズする $\tilde{X}$ 上の locally free sheaf の族で, 高次順像の消えるあの, $\varphi$ は $\pi * \mathscr{E} \mathrm{S}$ か $ら E_{S}\left(E_{R}\right.$ の $S \rightarrow \operatorname{Spec} R$ による引き戻し $) へ の$ 同型射。すると, $\mathscr{F}_{E_{R}}^{d}$ は, $R$ 上のスキームの圈から，集合の圈への反変函手で ある。申請者は,これに対して次の定理を証明している。

定理. $\mathscr{F}_{E_{R}}^{d}$ は SpecR 上の射影的なスキーム $f_{d}: F_{E_{R}}^{d} \rightarrow \operatorname{Spec} R$ により represent され，次の性質を持つ。

1. $\mathscr{F}_{E_{R}}^{d}$ は有限個の $d \in \operatorname{Pic}(\tilde{X})$ を除いて空である。

2. $\amalg_{d} f_{d}: \amalg_{d} \mathscr{F}_{E_{R}}^{d} \rightarrow \operatorname{Spec} R$ は全射である。

3. $S_{d}$ で $p \in \operatorname{Spec} R$ で $c_{1}\left(\tilde{E}_{k(p)}\right)=d$ となるような点全体の集合を表すと, Spec $R$ の stratification $\operatorname{Spec} R=\amalg_{i} S_{i}$ が得られ る。 $f_{d}^{-1}\left(S_{d}\right)$ は $(\mathscr{E}, \varphi) \in \mathscr{F}_{E_{R}}^{d}$ で, $\mathscr{E}$ が full sheaf になるようなあののなす開集合である。 $f_{d}$ にり $\mathrm{f}_{d}^{-1}\left(S_{d}\right)$ と $S_{d}$ は同型である。 4. $E_{R}$ が $\left(\right.$ Def'に関する) versal family の時は, 各 $\mathscr{F}_{E_{R}}^{d}$ と $S_{d}$ は non-singularである。

主論文においては mini-versal deformation $E_{R}$ に対する $\mathscr{F}_{E_{R}}^{d}$ の次元の公式も与えられている。また，有理特異点上の場 合には, $\operatorname{Def}_{E}$ は $\operatorname{Def}_{E}^{\prime}$ と同じ被約部分をむつ（がスキーム構造は一般には異なる）ことも示している。

第五節においては, 上の結果を具体的な場合, 特に有理二重点の場合に適用して詳しく調べている。有理二重点の場合,

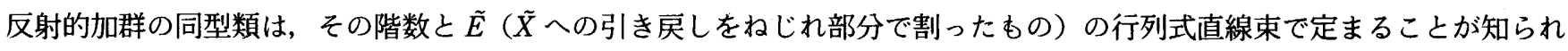


ている (Artin-Verdier) また, 有理二重点上の反射的加群 $E$ の変形と $E$ に自由加群を直和したあのの変形とは, 同一視する ことができる。この同一視と Artin-Verdier の定理とにより，反射的加群をルート系の dominant weight と対応させるこ とができる。

定理. 定理 4. 9 の stratification は同型類に基づくものである。反射的加群の間の变形による順序と dominant weight の間の表現論による順序とが対応する。Def' る有理二重点であるか, 射影空間の余接束の零切断を一点につぶしたあのである。

$A$ 型の場合に $\operatorname{Def}_{E}$ を需零行列のなすスキームを用いて記述したのが参考論文であり，主論文と合わせると上記の stratification の記述は Kraft-Procesi による䨌零多様体の stratification の記述と一致することがわかる。

\section{論文窨查の結果の要旨}

代数多様体に対して，その上の何らかの構造のモデュライ空間というのは，一般にその多様体に付随する重要な空間であ ると考えられる。例えば，射影的代数多様体上のベクトル束，あるいは捻れのない連接層のモデュライ空間は，ゲージ理論 や数理物理学との関わりの中で活発に研究され, 代数幾何学の中心的話題の一つである。申請者は, 孤立特異点上の加群の 変形空間について研究している。これは，射影多様体に対する連接層のモデュライに相当するあのと考えられ，また，特異 点をもつ射影多様体上の連接層のモデュライを扱う際には，必然的に考えなければならないあのである。

これまでに, 曲線の結節点上のある加群の変形については, Seshadri やFaltingsにより, 退化した射影曲線上の連接層の モデュライを研究するという観点から具体的に調べられていたが，2次元以上の場合に加群の変形問題を正面から扱ったも のは見受けられず，申請者の論文はその端緒を開くあのである。

申請者の論文を見てみよう。まず最初に，申請者は一般の孤立特異点 $X$ 上で孤立した特異点を持つ加群 $E$ のつの変形問 題を考察している。その一方である $\operatorname{Def}_{E}$ は $E$ の一般の変形に対応し， むう一方の $\operatorname{Def}_{E}^{\prime}$ は determinant を保った $E$ の変形 に対応したあのである。申請者は Schlessinger, Artin，そして Elkik の手法及び結果に従い次のような一般的な結果を得て いる: 上の二つの変形問題は, effectively pro-representable であり,さらに mini-versal deformation space は代数化され る，すなわち, essentially of finite type である局所か代数の Hensel 化として構成される。これは, 加群の変形問題を扱う にあたっては出発点どなる基本的かつ重要な結果である。

申請者の論文の中で, 最も興味深くかつ驚くべき結果は, $X$ が 2 次元の有理二重点である場合に得られている。この場合,

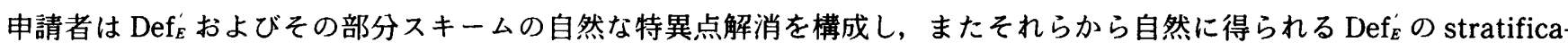
tion が, 同型類を考えることにより得られるすのと一致することを示している。これから，申請者は minimal strata の閉包 の特異点は，あとあとの Dynkin 図形の部分図形に対応する有理二重点であるか，射影空間の余接束の零切断をつぶして得 られるシンプレクティックな特異点のどちらかである，という美しい結果を導いている。特に，Eがある階数 2 の加群であ るとき, $\operatorname{Def}_{E}^{\prime}$ は $X$ に同型である。（申請者はまた $\operatorname{Def}_{E}$ と $\operatorname{Def}_{E}^{\prime}$ は同じ披約部分を持っことを示し，また一般にはこれらは同 型でないということを注意している。）この点で, 申請者の結果は, 半単純代数群における需零軌道の閉包についての Kraft と Procesiによる記述を強く想起させるものである。またこの結果は, 中島啓によるALE 空間上のインスタントンのモ デュライの䈨多様体を用いた記述との強い関連を示唆している。

さらに，一般の 2 次元有理特異点についても上記の構成は有効であり，またGoren-stein 孤立特異点の場合にあ興味深い 現象が観察されるなど, 加群の変形空間は特異点の幾何学にとって重要な空間であると考えられ，今後この方面の研究の発 展が期待される。

このように申請者の論文は, これまであまり研究されていなかった加群の変形空間というあのを独自の手法で研究し, 有 理二重点等の場合の美しい記述を見いだしたあのである。さらにさまざまな分野の研究とあ関連すると思われ，また今後の 発展あ期待できる。よって本申請論文は博士（理学）の学位論文として価値のあるむのとして認める。

なお平成 11 年 10 月 13 日, 主論文及び参考論文に報告されている研究業績を中心とし, それに関連した研究分野について 口頭試問した結果, 合格と認めた。 